\title{
Analisis Produksi Energi dari Inverter pada Grid-connected PLTS 1 MWp di Desa Kayubihi Kabupaten Bangli
}

\author{
A. A. Ngurah Bagus Budi Nathawibawa ${ }^{1}$ I Nyoman Satya Kumara ${ }^{2}$, Wayan Gede Ariastina ${ }^{3}$
}

\begin{abstract}
Inverter is a very important component of a gridconnected PV plant due to its function to convert $D C$ power output of the PV module to AC power. Inverter is built from many components to support its operation so it is the most complex component in a PV systems. The $1 \mathrm{MWp}$ grid-connected Kayubihi PV Plant uses 50 units of $20 \mathrm{~kW}$ inverter. This research is aimed to obtain inverters performance also the effect of string array position to energy production of the plant. Energy production analysis of the plant is conducted by mapping the energy production percentage of each inverter, then inverter with the highest energy production percentage is nominated as the reference to measure the performance of other inverters. The analysis considers string array location which connected to the inverter too and also based on the site condition of PV location. It is found that that the highest energy production is shown by inverter 44-E5 with energy output of $17.827 \mathrm{kWh}$ and the lowest is inverter 8-D3 at $8.898 \mathrm{kWh}$. The highest average energy production is inverter $44-\mathrm{E} 5$ at $72,47 \mathrm{kWh} / \mathrm{day}$, and the lowest is inverter 11-C5 at 39,26 kWh/day. Based on the analysis, it can be concluded that all inverter in Kayubihi PV Plant has its energy production greater than or equal to $75 \%$ of the optimum energy output of string array and the inverter 29-B9 has the highest energy production percentage.
\end{abstract}

Intisari-Inverter merupakan komponen yang sangat penting dalam sebuah PLTS yang terhubung dengan jaringan listrik karena fungsinya untuk mengubah daya keluaran DC modul surya menjadi daya AC. Inverter dibangun dari berbagai macam komponen untuk menunjang operasinya, sehingga inverter adalah komponen paling kompleks di dalam sistem PLTS. Grid-connected PLTS 1 MWp Kayubihi menggunakan 50 unit inverter dengan kapasitas masing-masing $20 \mathrm{~kW}$. Penelitian ini bertujuan untuk mengetahui unjuk kerja inverter serta pengaruh posisi string array terhadap produksi energi PLTS. Analisis produksi energi di PLTS Kayubihi dilakukan dengan memetakan persentase produksi energi dari setiap inverter, kemudian inverter dengan persentase produksi energi tertinggi dipilih sebagai acuan untuk menilai unjuk kerja dari 49 inverter yang lain. Analisis juga memperhatikan letak string array yang terhubung dengan inverter serta berdasarkan kondisi di lokasi PLTS terpasang. Diperoleh bahwa produksi energi tertinggi dihasilkan oleh inverter 44-E5 sebesar $17.827 \mathrm{kWh}$ dan terendah adalah inverter 8-D3 sebesar $8.898 \mathrm{kWh}$. Inverter dengan produksi energi rata-rata tertinggi adalah inverter 44-E5 sebesar 72,47 $\mathrm{kWh} / \mathrm{hari}$ dan terendah adalah inverter 11-C5 sebesar $39,26 \mathrm{kWh} / \mathrm{hari}$. Berdasarkan analisis yang telah dilakukan,

${ }^{1}$ Mahasiswa, Jurusan Teknik Elektro dan Komputer Fakultas Teknik Universitas Udayana, Jalan Gunung Semeru, No. 10 Denpasar 80118 (Hp: 085935294550; telp: 0361-8473695; e-mail: ngurah.bagus93@yahoo.com)

${ }^{2,3}$ Staf Pengajar Jurusan Teknik Elektro dan Komputer Fakultas Teknik Universitas Udayana, Jalan Kampus Bukit Jimbaran 80361 INDONESIA (telp: 0361-703315; fax: 0361-4321) dapat disimpulkan bahwa seluruh inverter di PLTS Kayubihi, produksi energinya sudah lebih besar atau sama dengan $75 \%$ sesuai keluaran energi optimum string array masing-masing, dengan inverter 29-B9 memiliki persentase produksi energi tertinggi.

Kata Kunci- Energi Terbarukan, PLTS On-grid, Unjuk Kerja Inverter, Produksi Energi

\section{Pendahuluan}

Pembangkit Listrik Tenaga Surya (PLTS) merupakan suatu sistem yang mampu mengubah sinar matahari menjadi tenaga listrik. Inverter adalah salah satu subsistem penting yang diperlukan untuk mencatu beban AC atau jika PLTS tersebut terhubung dengan jaringan PLN karena inverter mampu mengubah daya DC menjadi daya AC.

Tahun 2025 PLTS diharapkan dapat menyumbang 0,87 GW, dimana beserta energi biomassa, nuklir, air dan angin dapat mencapai target sebesar $5 \%$ dari keseluruhan EBT sebesar $17 \%$ dari kapasitas pembangkitan listrik nasional [1]. Bahwa untuk mencapai hal tersebut diperlukan berbagai upaya antara lain memperluas penggunaan PLTS di masyarakat khususnya masyarakat urban atau di wilayahwilayah yang sudah terkangkau jaringan distribusi PLN dan tetap menjalankan program-program kelistrikan pada wilayahwilayah terpencil dengan pemasangan solar home system (SHS) [2].

Secara umum bagian utama sebuah inverter adalah semikonduktor daya sebagai sakelar, DC link bus, kontroler dan sistem pengaman. Inverter juga dilengkapi rangkaian kontrol PWM, algoritma phase locked loop (PLL) serta phase detector. Dewasa ini inverter juga sudah dilengkapi fitur untuk merekam data (data logging) untuk memantau unjuk kerja operasinya dalam kurun waktu tertentu serta dilengkapi juga fasilitas antarmuka pengguna untuk menampilkan data tegangan, arus, frekuensi serta arus dan tegangan beban. Banyaknya komponen dan fitur tersebut membuat inverter menjadi sebuah sistem yang kompleks namun harus beroperasi pada keadaan lingkungan yang berubah-ubah. Inilah yang menyebabkan inverter harus memiliki tingkat keandalan tinggi. Komponen dengan keandalan yang tinggi dibutuhkan untuk meminimalisir downtime inverter dan secara tidak langsung juga meminimalisir biaya pemeliharaan [3], [4]. Banyak penelitian yang telah dilakukan mengenai unjuk kerja inverter seperti yang ditunjukkan [5], [6], [7], [8], [9].

Salah satu PLTS grid-connected terbesar di Bali adalah PLTS yang terletak di Desa Kayubihi Kabupaten Bangli atau yang disebut PLTS Kayubihi. Total daya pembangkitan maksimum PLTS Kayubihi adalah 1 MWp. PLTS Kayubihi menggunakan string inverter dengan kapasitas $20 \mathrm{~kW}$ 
sebanyak 50 unit. PLTS tersebut berada pada ketinggian \pm 870 meter diatas permukaan laut, dengan curah hujan di Kabupaten Bangli $1.947 \mathrm{~mm} /$ bulan serta kelembaban 68\% dengan suhu $15{ }^{\circ} \mathrm{C}-30{ }^{\circ} \mathrm{C}$. Jenis tanah di Bangli adalah tanah regosal, sehingga tanaman apa saja bisa tumbuh di daerah ini. Faktor pendukung secara alami ini menopang Bangli memiliki lahan subur yang sangat potensial di sektor pertanian [10].

Secara teoritis suhu di PLTS Kayubihi mendekati standard test conditions (STC), dengan suhu harian $23,8{ }^{\circ} \mathrm{C}$. Namun curah hujan dan hari hujan di sekitar PLTS juga cukup tinggi sehingga dapat berdampak pada produksi energi PLTS. Berdasarkan observasi di lapangan, faktor lain yang dapat berdampak terhadap sistem PLTS adalah bayangan dari rumput dan pepohonan yang tinggi [11].

Penelitian mengenai unjuk kerja inverter PLTS Kayubihi dilakukan menggunakan data record sistem monitoring tahun 2014. Data record sistem monitoring diolah untuk memperoleh produksi energi inverter. Kemudian dilakukan analisis dengan memetakan persentase produksi energi sesuai dengan letak string array yang terhubung dengan inverter, menggunakan inverter dengan persentase produksi tertinggi sebagai acuan untuk menilai unjuk kerja inverter lainnya, serta melakukan observasi lapangan. Dengan demikian diharapkan dapat diketahui bagaimana unjuk kerja inverter PLTS Kayubihi dari segi produksi energi serta penyebabnya.

\section{KAJIAN PUSTAKA}

\section{A. PLTS Grid-connected}

Sistem PLTS on-grid atau grid-connected PV system pada dasarnya menggabungkan PLTS dengan jaringan listrik (PLN). Komponen utama sisten ini adalah Power Conditioning Unit (PCU) atau inverter yang berfungsi untuk mengubah daya DC yang dihasilkan PLTS menjadi daya AC yang disesuaikan dengan persyaratan jaringan listrik yang terhubung (utility grid). Selain itu juga menghentikan secara otomatis suplai daya ke jaringan listrik ketika utility grid tidak mengalirkan daya [12].

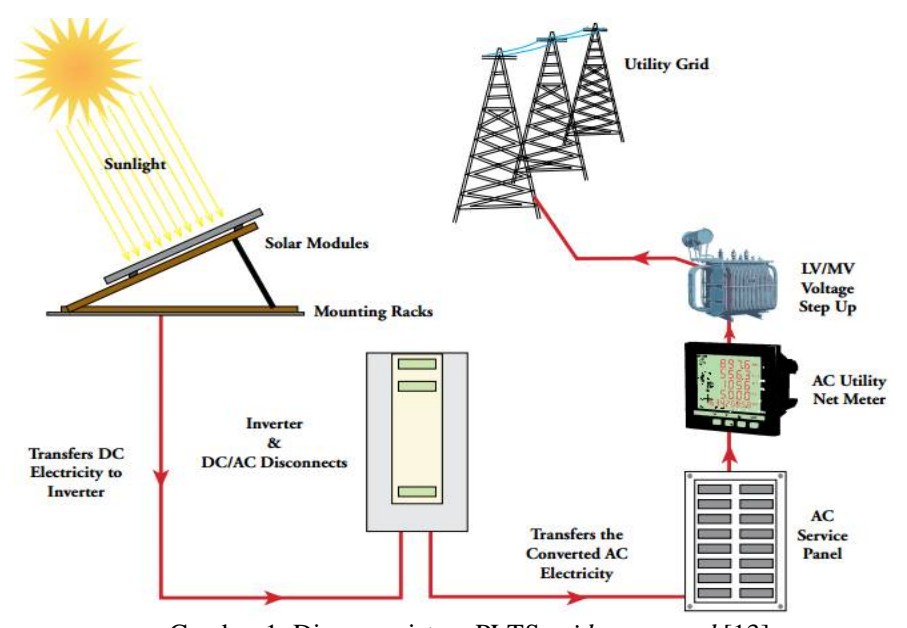

Gambar 1: Diagram sistem PLTS grid-connected [13]

\section{B. Faktor-faktor yang Mempengaruhi Produksi Energi Modul Surya}

Faktor-faktor utama yang mempengaruhi produksi energi listrik modul surya adalah sebagai berikut [14]:

1) Iradiasi: Pada saat iradiasi menurun, arus yang dihasilkan modul surya akan menurun secara proporsional, sedangkan perubahan tegangan tanpa beban sangat kecil. Kurva karakteristik V-I ditunjukkan pada Gambar 2 yaitu fungsi iradiasi terhadap sel surya yang mempengaruhi arus dan tegangan.

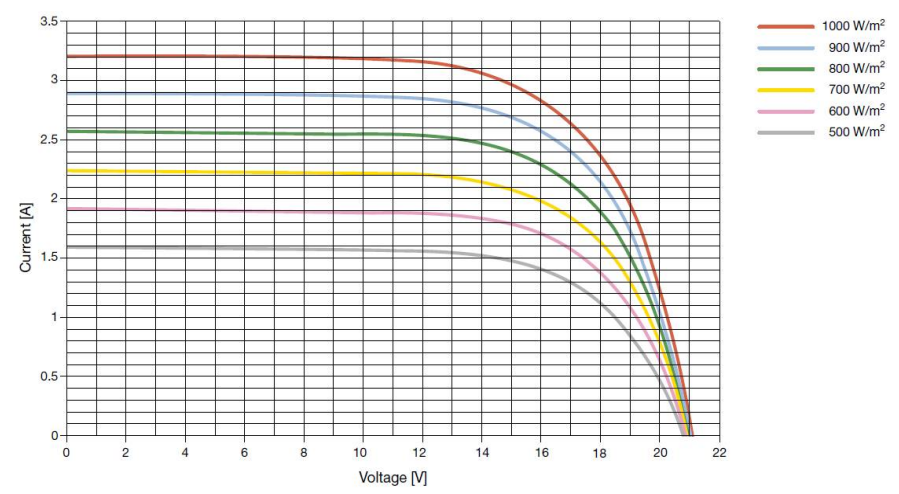

Gambar 2: Iradiasi matahari terhadap arus dan tegangan modul surya [14]

2) Suhu Modul: Berkebalikan dengan pengaruh iradiasi, ketika suhu modul meningkat, arus yang dihasilkan praktis tidak berubah, sedangkan tegangan menurun dan dengan demikian kemampuan panel dalam menghasilkan energi listrik juga menurun. Penurunan efisiensi adalah berkisar 0,4 hingga 0,6 untuk setiap peningkatan $1{ }^{\circ} \mathrm{C}$.

3) Bayangan: Ketika tertutup oleh bayangan, sambungan P-N di dalam sel surya berhenti memproduksi energi dan menjadi beban pasif. Sel ini berperilaku seperti sebuah diode yang memblok arus yang diproduksi oleh sel-sel lainnya yang terhubung seri, sehingga membahayakan produksi modul. Selain itu juga dapat menyebabkan panas berlebih dan kerusakan pada modul.

4) Inklinasi dan Orientasi Panel Surya: Efisiensi terbesar panel surya tercapai jika sudut datang sinar matahari selalu $90^{\circ}$. Sesungguhnya datangnya sinar matahari bervariasi menurut garis lintang serta deklinasi matahari sepanjang tahun. Karena kemiringan sumbu rotasi bumi sekitar $23,45^{\circ}$ terhadap bidang orbit bumi terhadap matahari, tempat terbit dan terbenamnya mathari selalu bervariasi setiap harinya. Matahari berada di posisi sudut $90^{\circ}$ terhadap permukan bumi yaitu pada garis khatulistiwa.

\section{PLTS Kayubihi}

PLTS Kayubihi berdiri diatas lahan total seluas kurang lebih $18.450 \mathrm{~m}^{2}$, dimana sekitar $8.700 \mathrm{~m}^{2}$ bidang lahannya digunakan untuk modul surya/array sebagai penghasil tenaga listrik. Secara astronomis PLTS Kayubihi terletak pada koordinat $-8,35^{\circ}$ lintang selatan (latitude) dan $115,36^{\circ}$ bujur timur (longitude) dan pada ketinggian $\pm 872 \mathrm{~m}$ dpl [15]. 


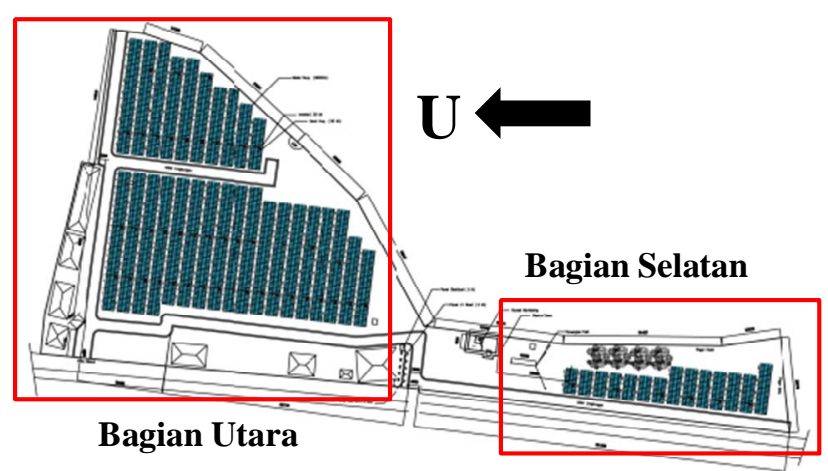

Gambar 3: Tampak atas PLTS Kayubihi [11] [15]

PLTS Kayubihi dengan daya nominal 1 MWp termasuk ke dalam PLTS skala besar [16]. Berdasarkan sistem pemasangannya, PLTS Kayubihi merupakan sistem PLTS terpusat (centralized PV system) yang terhubung ke jaringan listrik ( $g r i d$ ) tanpa menggunakan baterai/sistem penyimpanan. PLTS Kayubihi menggunakan inverter dengan konfigurasi string. Inverter yang digunakan adalah inverter gridconnected SUNGROW SG20KTL dengan kapasitas $20 \mathrm{~kW}$ sebanyak 50 unit.

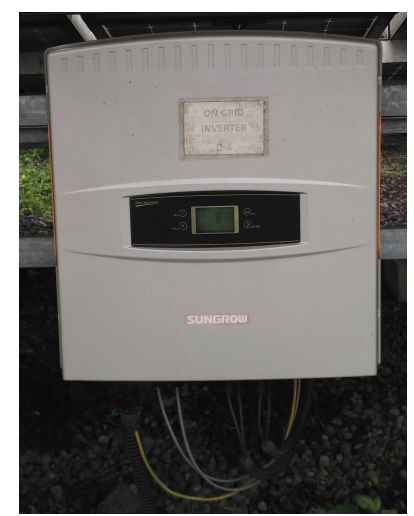

Gambar 4: Grid-connected inverter SG20KTL 20 kW

PLTS Kayubihi memiliki sistem monitoring yang berfungsi untuk menampilkan data dan informasi dari operasi sistem PLTS, yang sangat diperlukan untuk menganalisis unjuk kerja (performance ratio) dan jumlah energi yang diproduksi (harian, bulanan dan tahunan). Peralatan ini dipasang pada rumah monitoring dan digunakan untuk memantau operasi PLTS oleh operator.

Data yang diperoleh dari sistem monitoring berasal dari hubungan komunikasi komputer terhadap inverter dan peralatan stasiun cuaca atau disebut environmental monitoring device yang dipasang pada lokasi PLTS. Peralatan ini dilengkapi dengan sensor kecepatan angin, sensor arah angin, sensor radiasi matahari, sensor suhu lingkungan, sensor suhu modul surya dan kotak kontrol utama.

\section{METODE PENELITIAN}

Observasi awal PLTS Kayubihi untuk mengetahui sistem, konfigurasi, spesifikasi dan geografis lokasi penelitian. Mengumpulkan data record dari sistem monitoring PLTS
Kayubihi berupa laporan harian unjuk kerja PLTS, kondisi lingkungan dan energi listrik yang dihasilkan selama satu tahun dengan interval waktu 15 menit. Mengolah data record produksi energi dari sistem monitoring PLTS Kayubihi untuk menghitung produksi energi harian dan bulanan seluruh inverter serta total dan rata-rata produksi energi masingmasing inverter. Data produksi energi juga diolah untuk mendapatkan produksi energi berdasarkan $75 \%$ energi optimum masing-masing string array. Kemudian, melakukan analisis terhadap hasil pengolahan data produksi energi dengan memetakan letak inverter beserta persentase $\geq 75 \%$ energi optimum string array serta membandingkan persentase produksi energi $\geq 75 \%$ yang tertinggi dengan yang lain disertai observasi lapangan untuk memperkuat hasil analisis.

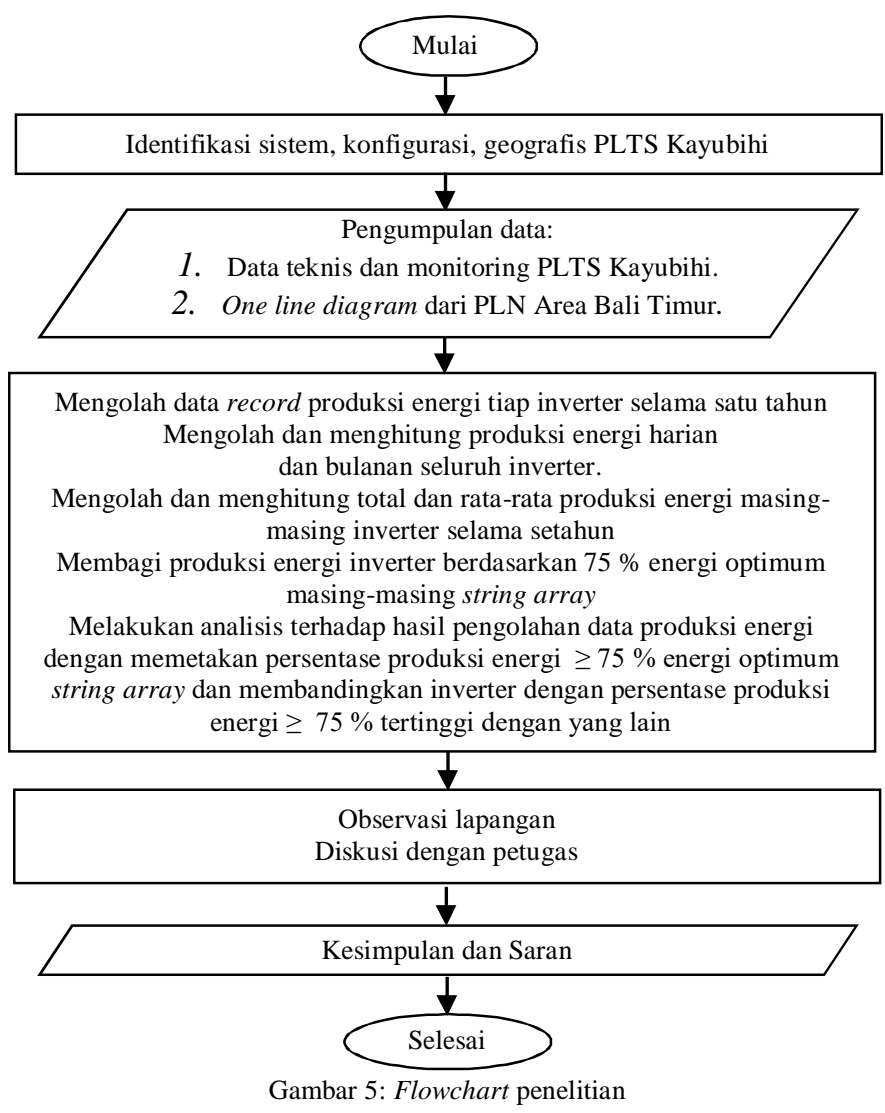

IV. HASIL DAN PEMBAHASAN

A. Spesifikasi Teknis PLTS Kayubihi

Berdasarkan observasi yang dilakukan [11], [15], PLTS Kayubihi memiliki 278 string array, dimana setiap array terdiri dari 18 buah modul surya yang dirangkai secara seri dengan susunan 3 baris dan 6 kolom. Inverter berjumlah 50 unit dimana sebanyak 22 inverter terhubung dengan 5 string array $\left(\mathrm{P}_{\mathrm{m}} \mathrm{STC}=17.839,8 \mathrm{~W}\right)$ dan 28 inverter terhubung dengan 6 string array $\left(\mathrm{P}_{\mathrm{m}} \mathrm{STC}=21.407,76 \mathrm{~W}\right)$. Seluruh daya listrik yang dibangkitkan PLTS Kayubihi disalurkan ke Jaringan Tegangan Menengah (JTM) PLN $20 \mathrm{kV}$ melalui 5 blok panel distribusi grup inverter dan 5 unit transformator step-up. Setiap transformator dihubungkan dengan satu grup inverter yang terdiri dari 10 unit string inverter. Sistem A. A. Ngurah Bagus Budi Nathawibawa: Analisis Produksi Energi dari ...
p-ISSN:1693 - 2951; e-ISSN: 2503-2372 


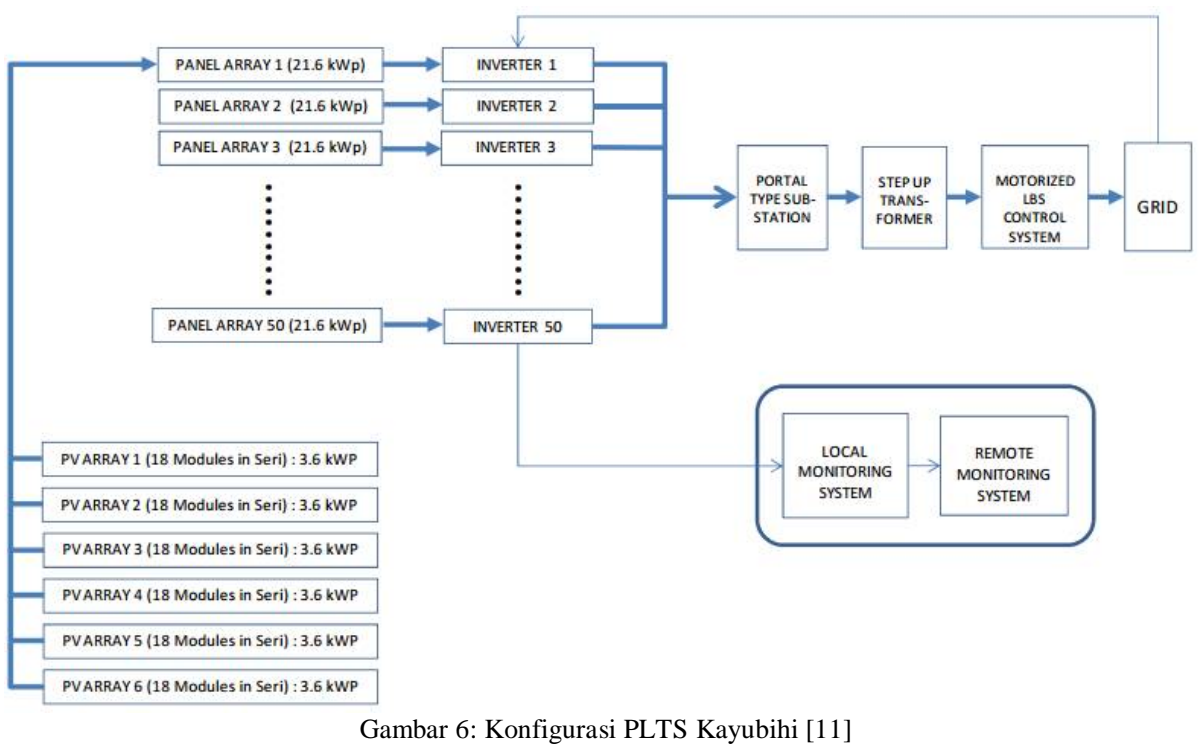

tegangan PLTS Kayubihi dibagi menjadi 3 sisi yaitu pada sisi pembangkitan/array tegangan nominal adalah $650 \mathrm{Vdc}$ hingga maksimum $1.000 \mathrm{Vdc}$, kemudian dikonversikan menjadi tegangan bolak-balik oleh string inverter dengan nominal tegangan 230/400 Vac, selanjutnya tegangan ini dinaikkan melalui transformator step up menjadi tegangan nominal 20 $\mathrm{kV}$, sesuai dengan tegangan nominal JTM PLN. Orientasi modul surya PLTS Kayubihi menghadap ke utara azimuth $0^{\circ}$, dengan kemiringan panel $15^{\circ}$ dan menggunakan penyangga tipe tetap.

\section{B. Produksi Energi Inverter PLTS Kayubihi}

Analisis produksi energi inverter PLTS Kayubihi dilakukan dengan mengolah data record produksi energi seluruh inverter dari sistem monitoring PLTS Kayubihi. Hasil pengolahan data ditampilkan pada Tabel I (Lampiran) yaitu mengenai total produksi energi seluruh inverter selama satu tahun. Identitas inverter yang tercetak miring pada Tabel I menandakan inverter tersebut terhubung dengan 6 string array, sedangkan yang tercetak tegak terhubung dengan 5 string array.

Tabel I menunjukkan produksi energi inverter selama satu tahun. Total produksi energi tertinggi adalah inverter 44-E5 sebesar $17.827 \mathrm{kWh}$ dan produksi energi terendah adalah inverter 8-D3 sebesar $8.898 \mathrm{kWh}$. Produksi energi inverter 44E5 tertinggi, disebabkan oleh jumlah array yang terhubung sebanyak 6 string array sehingga produksi energi secara ideal lebih besar dibandingkan 5 string array serta didukung pula oleh letak modul atau string array yang cukup mendapat paparan sinar matahari. Inverter 1-D5 hingga 10-D1 (grup D) diketahui empty record sejak tanggal 13 Agustus 2014, sehingga bulan September hingga Desember tidak ada produksi energi.

Data record sistem monitoring juga diolah untuk mendapatkan rata-rata produksi energi harian seluruh inverter selama setahun dan ditampilkan pada Tabel II (Lampiran). Identitas inverter yang tercetak miring pada Tabel II menandakan inverter tersebut terhubung dengan 6 string array, sedangkan yang tercetak tegak terhubung dengan 5 string array.

Jika dilihat berdasarkan rata-rata produksi energi harian seperti yang ditunjukkan pada Tabel II, selama satu tahun rata-rata produksi energi inverter 44-E5 adalah yang tertinggi yaitu sebesar $72,47 \mathrm{kWh} /$ hari, sedangkan rata-rata produksi energi inverter terendah adalah inverter 11-C5 sebesar 39,26 $\mathrm{kWh} /$ hari. Data tersebut menunjukkan bahwa string array yang terhubung dengan inverter 44-E5 konsisten mendapat paparan sinar matahari lebih tinggi dibanding yang lain serta didukung pula oleh jumlah string array yang lebih banyak (6 string array), sehingga produksi energi tahunan inverter 44E5 juga menjadi yang tertinggi seperti ditunjukkan pada Tabel I.

Tabel I dan II menunjukkan bahwa total dan rata-rata produksi energi inverter 11-C5 adalah yang terendah diluar inverter grup D (inverter 1-D5 hingga 10-D1) yang empty record. Setelah dilakukan analisis berdasarkan data record produksi energi dari sistem monitoring, diketahui bahwa produksi energi inverter 11-C5 menurun sejak tanggal 22 Februari 2014 seperti yang ditunjukkan pada Tabel III.

TABEL III

PENURUNAN PRODUKSI ENERGI INVERTER 11-C5

\begin{tabular}{|c|c|}
\hline \multicolumn{2}{|c|}{ Rata-rata Produksi Energi INV 11-C5 } \\
\hline$<22$ Februari 2014 & $61,11 \mathrm{kWh} / \mathrm{h}$ ari \\
\hline$\geq 22$ Februari 2014 & $34,50 \mathrm{kWh} / \mathrm{hari}$ \\
\hline
\end{tabular}

Analisis lebih lanjut dilakukan terhadap inverter 11-C5 dari segi daya puncak. Diketahui bahwa berdasarkan data record daya puncak sistem monitoring, penurunan produksi energi disebabkan penurunan daya puncak DC seperti yang ditunjukkan pada Tabel IV, sehingga penurunan produksi energi disebabkan karena daya masukan yang menurun, bukan gangguan pada inverter. Penurunan daya masukan ini dapat disebabkan oleh kerusakan pada modul surya atau instalasi yang kurang baik. 
TABEL IV

PENURUNAN DAYA PUNCAK DC INVERTER 11-C5

\begin{tabular}{|c|c|c|}
\hline Tanggal & Daya Puncak DC (kW) & Rata-rata $(\mathrm{kW})$ \\
\hline $15-\mathrm{Feb}-14$ & 21,78 & \multirow{7}{*}{24,49} \\
\hline $16-\mathrm{Feb}-14$ & 22,43 & \\
\hline $17-F e b-14$ & 25,62 & \\
\hline 18 -Feb-14 & 23,99 & \\
\hline 19-Feb-14 & 20,50 & \\
\hline $20-F e b-14$ & 28,18 & \\
\hline $21-F e b-14$ & 28,96 & \\
\hline $22-\mathrm{Feb}-14$ & 11,20 & \multirow{7}{*}{11,18} \\
\hline $23-F e b-14$ & 17,14 & \\
\hline $24-F e b-14$ & 13,22 & \\
\hline $25-\mathrm{Feb}-14$ & 13,67 & \\
\hline 26-Feb-14 & 7,96 & \\
\hline $27-F e b-14$ & 11,19 & \\
\hline $28-F e b-14$ & 3,87 & \\
\hline
\end{tabular}

Kemudian dilakukan juga analisis dari segi efisiensi inverter 11-C5. Data yang diambil untuk mendapatkan efisiensi diperoleh dari "running information records" yang tersimpan dalam jangka waktu 30 hari di data logger inverter. Pengambilan data dilakukan 3 kali sehari selama 7 hari dan kemudian dihitung efisiensinya. Analisis ini dilakukan untuk melihat apakah inverter mengalami penurunan dari segi efisiensi sehingga jumlah energi yang dikonversi juga menurun. Setelah dilakukan analisis diketahui bahwa rata-rata efisiensi inverter 11-C5 adalah 97,98 \% dan mendekati efisiensi spesifikasi teknis inverter SG20KTL sebesar $98 \%$. Hasil ini menunjukkan bahwa kemampuan inverter 11-C5 dalam mengkonversi daya DC menjadi AC masih mendekati standard yang ditentukan produsen.

TABEL V

EFISIENSI INVERTER 11-C5

\begin{tabular}{|c|c|c|c|c|c|}
\hline \multirow{2}{*}{ Tanggal } & Waktu & $\begin{array}{c}\text { Pdc1 } \\
(\mathbf{W})\end{array}$ & $\begin{array}{c}\text { Pdc2 } \\
(\mathbf{W})\end{array}$ & Pac $(\mathbf{W})$ & Effisiensi (\%) \\
\hline \multirow{3}{*}{ 16-Apr-16 } & 09.00 & 2233 & 2171 & 4315 & 97,98 \\
\cline { 2 - 6 } & 12.00 & 5116 & 5115 & 10026 & 98,00 \\
\cline { 2 - 6 } 17-Apr-16 & 15.00 & 216 & 216 & 423 & 97,92 \\
\cline { 2 - 6 } & 09.00 & 2065 & 2003 & 3986 & 97,98 \\
\cline { 2 - 6 } & 12.00 & 4687 & 4684 & 9183 & 97,99 \\
\hline \multirow{3}{*}{ 18-Apr-16 } & 15.00 & 753 & 754 & 1476 & 97,94 \\
\cline { 2 - 6 } & 09.00 & 2269 & 2208 & 4387 & 97,99 \\
\cline { 2 - 6 } & 12.00 & 5220 & 5218 & 10229 & 98,00 \\
\hline \multirow{3}{*}{ 20-Apr-16 } & 15.00 & 2044 & 1983 & 3946 & 97,99 \\
\cline { 2 - 6 } & 09.00 & 2396 & 2334 & 4635 & 97,99 \\
\cline { 2 - 6 } & 12.00 & 4563 & 4560 & 8940 & 97,99 \\
\cline { 2 - 6 } & 15.00 & 1733 & 1736 & 3399 & 97,98 \\
\cline { 2 - 6 } & 09.00 & 2351 & 2288 & 4546 & 98,00 \\
\hline \multirow{3}{*}{$21-$ Apr-16 } & 12.00 & 417 & 417 & 817 & 97,96 \\
\cline { 2 - 6 } & 09.00 & 355 & 355 & 695 & 97,89 \\
\cline { 2 - 6 } & 12.00 & 2744 & 2742 & 5376 & 97,97 \\
\hline \multirow{3}{*}{ 22-Apr-16 } & 15.00 & 3488 & 3486 & 6834 & 97,99 \\
\cline { 2 - 6 } & 09.00 & 2280 & 2220 & 4409 & 97,98 \\
\cline { 2 - 6 } & 12.00 & 5080 & 5080 & 9956 & 97,99 \\
\hline & 15.00 & 1472 & 1413 & 2827 & 97,99 \\
\hline
\end{tabular}

Inverter tidak terhubung dengan string array yang sama (5 atau 6 string array), sehingga energi yang dihasilkan juga tidak sama. Maka dari itu dilakukan perhitungan untuk melihat bagaimana produksi energi masing-masing inverter berdasarkan jumlah string array. Perhitungan produksi energi dilakukan berdasarkan $75 \%$ daya puncak dari 5 dan 6 string array dikali dengan peak sun hours PLTS Kayubihi. Referensi [15] menunjukkan bahwa peak sun hours di PLTS Kayubihi rata-rata sebesar 3,202 jam/hari. Sehingga perhitungan produksi energi berdasarkan $75 \%$ energi optimum string array adalah sebagai berikut:

\section{$\mathrm{P}_{\mathrm{m} \text { STC }} 5$ string array $=17,8398 \mathrm{~kW}$}

Sehingga $75 \%$ dari $17,8398 \mathrm{~kW}=13,37985 \mathrm{~kW}$

Maka, produksi energi dari $75 \%$ daya puncak 5 string array: $13,37985 \mathrm{~kW}$ x 3,202 jam $=42,84 \mathrm{kWh}$

$\mathrm{P}_{\mathrm{m} \text { STC }} 6$ string array $=21,40776 \mathrm{~kW}$

Sehingga $75 \%$ dari $21,40776 \mathrm{~kW}=16,05582 \mathrm{~kW}$

Maka, produksi energi dari $75 \%$ daya puncak 6 string array: $16,05582 \mathrm{~kW}$ x 3,202 jam $=51,41 \mathrm{kWh}$

Hasil perhitungan diatas kemudian diaplikasikan ke dalam seluruh data record produksi energi inverter, sehingga diketahui apakah produksi energi $\geq 75 \%$ dari energi optimum masing-masing string array atau tidak. Kemudian, untuk mengetahui berapa banyak produksi energi yang sudah $\geq 75 \%$ dari energi optimum masing-masing string array, hasil tersebut dirata-ratakan selama satu tahun, sehingga dapat disusun Tabel VI dan VII.

TABEL VI

PERSENTASE PRODUKSI ENERGI INVERTER TAHUN 2014 BERDASARKAN $75 \%$ ENERGI OPTIMUM 6 STRING ARRAY

\begin{tabular}{|l|c|c|}
\hline Inverter & $\begin{array}{c}\text { Persentase Produksi Energi } \\
\mathbf{5 1 , 4 1} \mathbf{k W h}\end{array}$ & $\begin{array}{c}\text { Persentase Produksi Energi } \\
\mathbf{3} \mathbf{5 1}, \mathbf{4 1} \mathbf{k W h}\end{array}$ \\
\hline INV 1-D5 & 40,46 & 59,54 \\
\hline INV 2-D6 & 23,92 & 76,08 \\
\hline INV 3-D7 & 23,08 & 76,92 \\
\hline INV 4-D8 & 29,32 & 70,68 \\
\hline INV 5-D9 & 30,32 & 69,68 \\
\hline INV 6-D10 & 31,99 & 68,01 \\
\hline INV 7-D4 & 30,32 & 69,68 \\
\hline INV 8-D3 & 57,10 & 42,90 \\
\hline INV 9-D2 & 30,75 & 69,25 \\
\hline INV 10-D1 & 19,37 & 80,63 \\
\hline INV 11-C5 & 82,12 & 17,88 \\
\hline INV 12-C4 & 23,07 & 76,93 \\
\hline INV 13-C2 & 22,66 & 77,34 \\
\hline INV 14-C1 & 20,07 & 79,93 \\
\hline INV 15-A10 & 23,27 & 76,73 \\
\hline INV 21-A4 & 24,65 & 75,35 \\
\hline INV 22-A3 & 20,76 & 79,24 \\
\hline INV 23-A2 & 27,19 & 72,81 \\
\hline INV 24-A1 & 27,71 & 72,29 \\
\hline INV 25-C7 & 34,42 & 65,58 \\
\hline INV 26-C6 & 21,92 & 78,08 \\
\hline INV 27-C3 & 28,81 & 71,19 \\
\hline INV 38-C8 & 31,25 & 68,75 \\
\hline INV 39-C9 & 21,69 & 78,31 \\
\hline INV 40-E1 & 23,72 & 76,28 \\
\hline INV 41-C10 & 21,01 & 78,99 \\
\hline INV 42-E4 & 20,49 & 79,51 \\
\hline INV 44-E5 & 20,34 & 79,66 \\
\hline
\end{tabular}

Berdasarkan Tabel VI dapat dilihat bahwa inverter dengan 6 string array dalam satu tahun mampu menghasilkan energi $\geq 75 \%$ dari energi optimum 6 string array atau $\geq 51,41 \mathrm{kWh}$. Produksi energi tertinggi adalah inverter 10-D1 yang 
menghasilkan energi $\geq 51,41 \mathrm{kWh}$ rata-rata sebesar $80,63 \%$ sedangkan yang terendah adalah inverter 11-C5 dengan ratarata sebesar 17,88 \% selama tahun 2014. Seperti sudah dijelaskan sebelumnya bahwa inverter 11-C5 sudah mengalami penurunan daya puncak dan produksi energi sejak 22 Februari 2014.

TABEL VII

PERSENTASE PRODUKSI ENERGI INVERTER TAHUN 2014 BERDASARKAN $75 \%$ ENERGI OPTIMUM 5 STRING ARRAY

\begin{tabular}{|l|c|c|}
\hline \multicolumn{1}{|c|}{ Inverter } & $\begin{array}{c}\text { Persentase Produksi } \\
\text { Energi }<\mathbf{4 2 , 8 4} \mathbf{~ k W h}\end{array}$ & $\begin{array}{c}\text { Persentase Produksi Energi } \\
\mathbf{2 4 2 , 8 4} \mathbf{~} \mathbf{W h}\end{array}$ \\
\hline INV 16-A9 & 20,22 & 79,78 \\
\hline INV 17-A8 & 24,61 & 75,39 \\
\hline INV 18-A7 & 26,10 & 73,90 \\
\hline INV 19-A6 & 18,27 & 81,73 \\
\hline INV 20-A5 & 20,29 & 79,71 \\
\hline INV 28-B10 & 19,80 & 80,20 \\
\hline INV 29-B9 & 16,79 & 83,21 \\
\hline INV 30-B8 & 18,25 & 81,75 \\
\hline INV 31-B7 & 17,92 & 82,08 \\
\hline INV 32-B6 & 29,09 & 70,91 \\
\hline INV 33-B5 & 21,03 & 78,97 \\
\hline INV 34-B4 & 19,80 & 80,20 \\
\hline INV 35-B3 & 24,65 & 75,35 \\
\hline INV 36-B2 & 20,49 & 79,51 \\
\hline INV 37-B1 & 29,64 & 70,36 \\
\hline INV 43-E2 & 18,72 & 81,28 \\
\hline INV 45-E6 & 20,73 & 79,27 \\
\hline INV 46-E3 & 31,59 & 68,41 \\
\hline INV 47-E7 & 22,56 & 77,44 \\
\hline INV 48-E8 & 28,82 & 71,18 \\
\hline INV 49-E9 & 21,54 & 78,46 \\
\hline INV 50-E10 & 20,19 & 79,81 \\
\hline
\end{tabular}

Kemudian, untuk Tabel VII menunjukkan inverter dengan 5 string array juga sudah mampu memproduksi energi $\geq 75 \%$ dari energi optimum 5 string array atau $\geq 42,84 \mathrm{kWh}$. Persentase tertinggi adalah inverter 29-B9 sebesar 83,21\% sedangkan persentase terendah adalah inverter 46-E3 sebesar $68,41 \%$. Selisih produksi energi dapat diakibatkan oleh luasnya area modul surya di PLTS Kayubihi terutama di bagian utara karena inverter dengan 5 string array hanya terdapat di PLTS bagian utara. Untuk lebih jelasnya, dilakukan analisis dengan cara pemetaan inverter sesuai dengan jumlah string array yang terhubung serta letaknya di lapangan seperti yang ditunjukkan pada Gambar 7 .

Gambar 7 menunjukkan dengan jelas bagaimana letak string array yang terhubung dengan inverter, sangat mempengaruhi produksi energi. Nilai yang ditunjukkan pada Gambar 7 sesuai dengan nilai pada Tabel VI dan VII. Nilai tersebut secara adil menunjukkan persentase produksi energi sesuai dengan $75 \%$ energi optimum masing-masing string array, bukan berdasarkan jumlah produksi energi yang tentunya dapat berbeda karena string array yang terhubung juga tidak sama.

Dapat dilihat pada Gambar 7 bahwa PLTS Kayubihi bagian selatan, persentase produksi energi tertinggi adalah sebesar 76,92 \% (persentase produksi energi yang berada $\geq$ $75 \%$ energi optimum string array) yaitu inverter 3-D7, dan terus menurun hingga inverter 6-D10 yang terletak paling selatan. Inverter dengan persentase produksi energi paling rendah adalah inverter 1 -D5 sebesar 59,54\%. Sedangkan pada
PLTS Kayubihi bagian utara, persentase produksi energi tertinggi adalah inverter 29-B9 dimana sebanyak 83,21\% energinya berada $\geq 75 \%$ dari energi optimum string array. Hal ini menarik karena string array inverter 29-B9 lebih sedikit dibandingkan inverter 1-D5 yang terhubung dengan 6 string array. Ini menunjukkan bahwa posisi string array yang terhubung dengan inverter 29-B9 lebih baik sehingga mendapat paparan sinar matahari yang lebih banyak dibandingkan dengan string array yang terhubung inverter 1D5.

\section{Bagian Utara}

\begin{tabular}{|c|c|c|c|c|c|c|c|}
\hline \multicolumn{4}{|c|}{ Jalan Lingkungan } & \multicolumn{4}{|c|}{ Jalan Lingkungan } \\
\hline$I N V 24-A I$ & 72,29 & INV 37-B1 & 70,36 & INV 38-C8 & 68,75 & & \\
\hline$I N V 23-A 2$ & 72,81 & INV 36-B2 & 79,51 & INV 39-C9 & 78,31 & $I N V 40-E I$ & 76,28 \\
\hline$I N V 22-A 3$ & 79,24 & INV 35-B3 & 75,35 & $I N V 4 I-C 10$ & 78,99 & & \\
\hline$I N V 21-A 4$ & 75,35 & INV $34-B 4$ & 80,2 & $I N V 42-E 4$ & 79,51 & INV 43-E2 & 81,28 \\
\hline INV 20-A5 & 79,71 & INV 33-B5 & 78,97 & INV 44-E5 & 79,66 & & \\
\hline \begin{tabular}{|l|} 
INV $19-\mathrm{A} 6$ \\
\end{tabular} & 81,73 & INV 32-B6 & 70,91 & INV 45-E6 & 79,27 & INV 46-E3 & 68,41 \\
\hline INV 18-A7 & 73,9 & INV 31-B7 & 82,08 & INV 47-E7 & 77,44 & & \\
\hline 砒 INV 17-A8 & 75,39 & INV $30-\mathrm{B} 8$ & 81,75 & INV 48-E8 & 71,18 & & \\
\hline INV $16-\mathrm{A} 9$ & 79,78 & INV 29-B9 & 83,21 & INV 49-E9 & 78,46 & & \\
\hline$I N V 15-A 10$ & 76,73 & INV 28-B10 & 80,2 & INV 50-E10 & 79,81 & & \\
\hline$I N V 14-C l$ & 79,93 & & & & & & \\
\hline$I N V 13-C 2$ & 77,34 & $I N V 27-C 3$ & 71,19 & & & & \\
\hline INV 12-C4 & 76,93 & & & & & & \\
\hline$I N V 11-C 5$ & 17,88 & INV 26-C6 & 78,08 & & & & \\
\hline INV 10-DI & 80,63 & & & & & & \\
\hline$I N V$ 9-D2 & 69,25 & $I N V 25-C 7$ & 65,58 & & & & \\
\hline$I N V 8-D 3$ & 42,90 & & & & & & \\
\hline INV 7-D4 & 69,68 & & & & & & \\
\hline
\end{tabular}

Bagian Selatan

\begin{tabular}{|c|c|c|}
\hline & $I N V 1-D 5$ & 59,54 \\
\hline & $I N V 2-D 6$ & 76,08 \\
\hline & $I N V 3-D 7$ & 76,92 \\
\hline & $I N V 4-D 8$ & 70,68 \\
\hline & INV 5-D9 & 69,68 \\
\hline & INV 6-D10 & 68,01 \\
\hline
\end{tabular}

Keterangan:

Cetak miring $=$ inverter dengan 6 string array Cetak tegak $=$ inverter dengan 5 string array

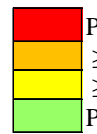

Persentase produksi energi $\geq 80 \%$ $\geq 75 \%$ Persentase produksi energi $<80 \%$ $\geq 70 \%$ Persentase produksi energi $<75 \%$ Persentase produksi energi $<70 \%$
Analisis kemudian dilakukan untuk melihat bagaimana daya harian inverter 29-B9 dan 1-D5 sehingga produksi energinya menjadi berbeda. Analisis dilakukan dengan melihat daya harian inverter 29-B9 sebagai inverter dengan persentase produksi energi $\geq 75 \%$ tertinggi di bagian utara dan inverter 1-D5 sebagai inverter dengan persentase produksi energi $\geq 75 \%$ terendah di bagian selatan. Daya harian yang ditampilkan dalam bentuk grafik pada Gambar 8 diperoleh dari rata-rata daya harian selama satu tahun dengan interval 15 menit sesuai data awal yang sudah diperoleh.

Gambar 8 menunjukkan bahwa daya harian inverter 29-B9 sebelum jam 12.00 lebih baik dibanding inverter 1-D5. Ini berarti bahwa di pagi hari posisi string array inverter 29-B9 lebih awal terpapar sinar matahari, ini juga berdampak pada produksi energi yang lebih besar. Walaupun pada pukul 12.00 hingga 14.00 dan pukul 14.15 hingga pukul 15.00 daya harian inverter 1-D5 diatas inverter 29-B9, namun tidak cukup mengurangi selisih yang terjadi pada pagi hari. Setelah pukul 15.00, daya harian kedua inverter cukup berhimpit atau hampir sama. Dengan demikian string array inverter 29-B9 
lebih banyak mendapat paparan sinar matahari dibandingkan dengan string array di inverter 1-D5 terutama di pagi hari.

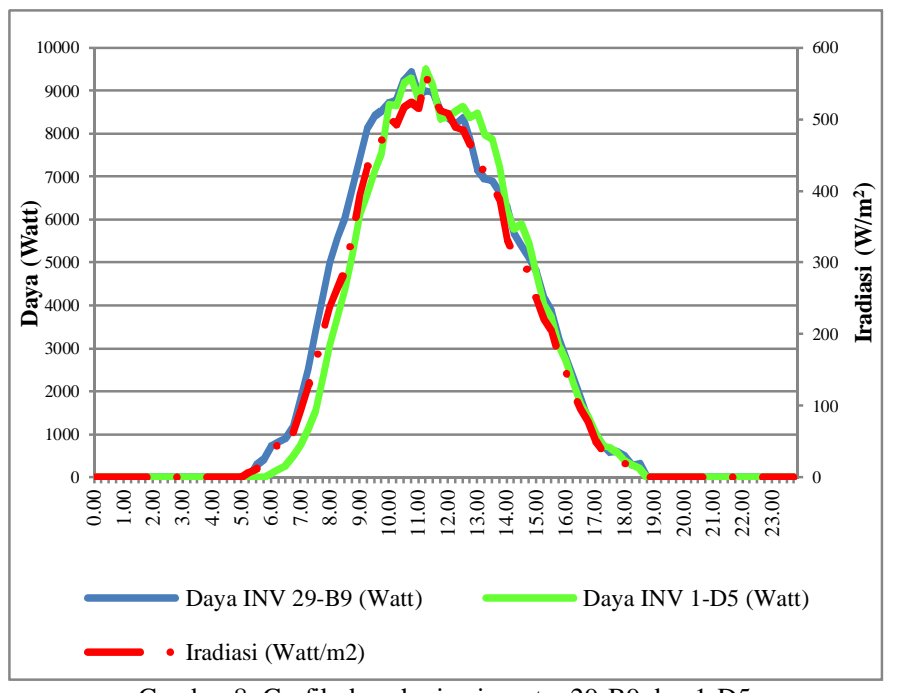

Gambar 8: Grafik daya harian inverter 29-B9 dan 1-D5

Kemudian dilakukan observasi di lapangan terkait dengan hasil analisis sebelumnya. Berdasarkan kondisi di lapangan pada saat penelitian dilakukan seperti yang ditunjukkan pada Gambar 9 dan 10, PLTS Kayubihi bagian selatan areanya sempit, kemudian disebelah timur terdapat semak belukar serta pepohonan yang tinggi dan disebelah barat terdapat pohon perindang jalan sehingga dapat menyebabkan iradiasi kurang optimal karena tertutupi oleh bayangan pepohonan, dibandingkan dengan PLTS Kayubihi bagian utara. Mengingat bahwa Kabupaten Bangli memiliki iklim yang sejuk serta tanah yang subur sehingga tumbuhan dengan mudah tumbuh subur begitu pula di dalam area PLTS Kayubihi. Hal ini sesuai dengan hasil analisis pada Gambar 8, dimana daya harian inverter 1-D5 pada pagi hari lebih lambat terpapar sinar matahari karena di sebelah timur string array terdapat semak belukar dan pepohonan yang cukup tinggi sehingga menghalangi sinar matahari.

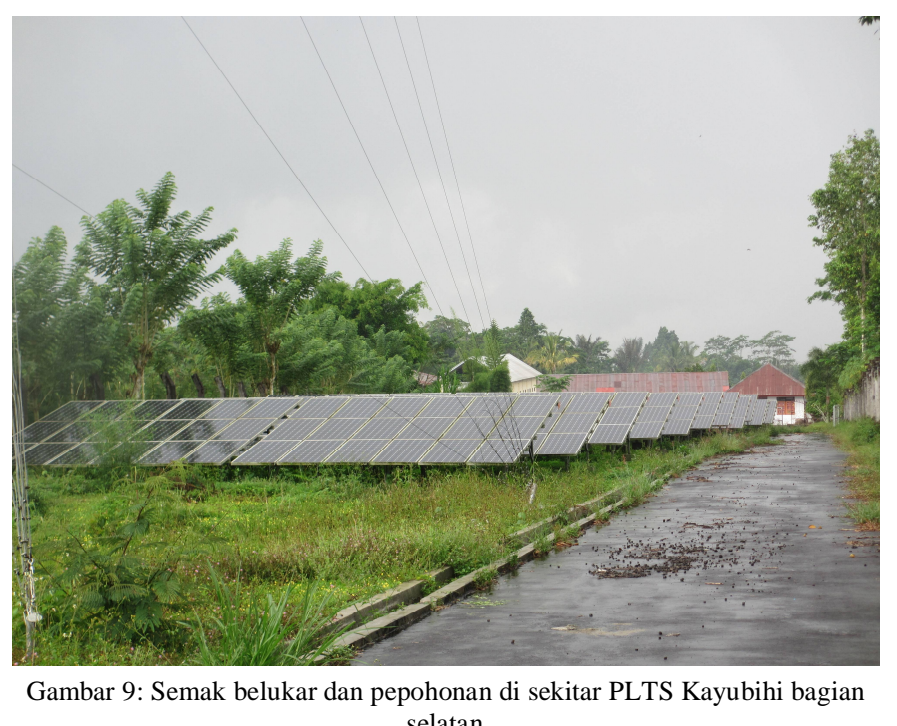

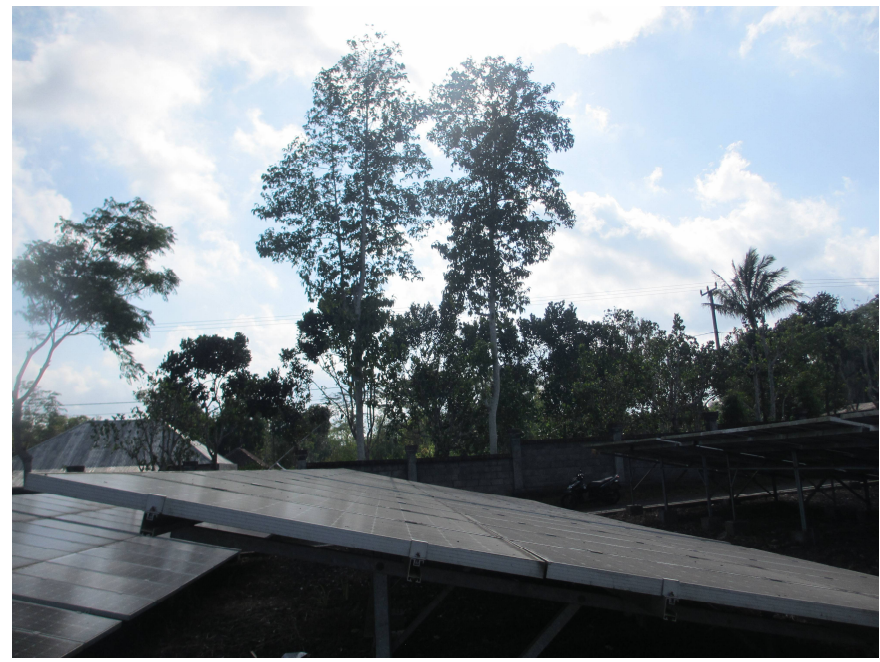

Gambar 10: Pohon perindang jalan di sisi barat bagian selatan

Pada PLTS Kayubihi bagian utara, persentase produksi energi lebih baik, disebabkan oleh area yang lebih luas dan lebih terbuka, sehingga iradiasi matahari lebih optimal terutama pada bagian tengah yang ditempati inverter 29-B9 seperti yang ditunjukkan pada Gambar 7 serta hasil analisis pada Gambar 8. Namun, produksi energi inverter di bagian utara PLTS juga bervariasi, karena luasnya area sehingga suatu waktu beberapa bagian PLTS dapat tertutupi oleh awan.

Secara keseluruhan, produksi energi inverter di PLTS Kayubihi sudah $\geq 75 \%$ dari energi optimum string array masing-masing. Ini menunjukkan bahwa modul surya di PLTS Kayubihi sudah mendapat paparan iradiasi matahari yang cukup untuk menghasilkan energi $\geq 75 \%$ dari energi optimum string array masing-masing. Hanya saja PLTS Kayubihi bagian selatan perlu mendapat perhatian lebih karena string array tertutup oleh bayangan semak belukar dan pepohonan pada saat penelitian dilakukan.

\section{Kesimpulan}

Berdasarkan hasil pengolahan dan analisis data record sistem monitoring dari segi produksi energi, serta observasi di lapangan, maka diperoleh hasil bahwa produksi energi tertinggi selama satu tahun adalah inverter 44-E5 sebesar $17.827 \mathrm{kWh}$ dan terendah adalah inverter 8-D3 sebesar 8.898 $\mathrm{kWh}$. Produksi energi rata-rata inveter tertinggi adalah inverter 44-E5 sebesar 72,47 kWh/hari dan terendah adalah inverter 11-C5 sebesar 39,26 kWh/hari.

Setelah dilakukan analisis berdasarkan daya puncak masing-masing string array serta peak sun hours di PLTS Kayubihi, seluruh inverter di PLTS Kayubihi menghasilkan rata-rata energi $\geq 75 \%$ dari energi optimum masing-masing string array, yaitu $\geq 42,84 \mathrm{kWh}$ untuk 5 string array dan $\geq$ $51,41 \mathrm{kWh}$ untuk 6 string array. Inverter 29-B9 adalah inverter dengan persentase produksi energi $\geq 75 \%$ energi optimum string array yang tertinggi sebesar 83,21\%.

Analisis yang telah dilakukan menunjukkan bahwa produksi energi inverter di PLTS Kayubihi dipengaruhi oleh letak modul surya yang terhubung dengan tiap-tiap inverter. Modul surya di bagian selatan PLTS persentase produksi

A. A. Ngurah Bagus Budi Nathawibawa: Analisis Produksi Energi dari ...

p-ISSN:1693 - 2951; e-ISSN: 2503-2372 
energi tertingginya lebih rendah dibandingkan dengan persentase produksi energi tertinggi di bagian utara. Observasi di lapangan menunjukkan keadaan di sekitar modul surya yang berada di PLTS Kayubihi bagian selatan, terdapat semak belukar serta pepohonan di sisi sebelah timur dan terdapat pohon perindang jalan di sisi sebelah barat, sehingga modul surya dapat tertutupi oleh bayangan pepohonan disekitarnya.

\section{REFERENSI}

[1] Kementerian Energi dan Sumber Daya Mineral Republik Indonesia. Blueprint Pengelolaan Energi Nasional 2006-2025. Jakarta: Kementerian ESDM. 2006.

[2] N. S. Kumara "Pembangkit listrik tenaga surya skala rumah tangga urban dan ketersediaannya di Indonesia". Majalah Ilmiah Teknologi Elektro. Vol. 9 No. 1.2010.

[3] L. M. Moore, and H. N. Post. "Five years of operating experience at a large, utility-scale photovoltaic generating plant". Journal of Prog. Photovoltaic. Volume 16 No. 3: 249-259. 2008.

[4] S. Yang, D. Xiang, A. Briant, P. Mawby, L. Ran and P. Tavner "Condition monitoring for device reliability in power electronic converters: a review". IEEE Transactions on Power Electronics. Volume 25: 2734-2752. 2010

[5] Z. J. Ma and S. Thomas. "Reliability and maintainability in photovoltaic inverter design". IEEE Reliability and Maintainability Symposium (RAMS). 10.1109/RAMS.2011.5754523. 2011.

[6] K. Chumpolrat, V. Sangsuwan, N. Udomdachanut, S. Kittisontirak, S. Songtrai, P. Chinnavornrungsee, A. Limmanee, J. Sritharathikhun, and K. Sriprapha. "Effect of ambient temperature on performance of gridconnected inverter installed in Thailand". International Journal of Photoenergy. Vol 2014. 2014.

[7] R. Kaplar, R. Brock, S. DasGupta, M. Marinella, A. Starbuck, A. Fresquez, S. Gonzalez, J. Granata, M. Quintana, M. Smith and S. Atcitty. "PV inverter performance and reliability: What is the role of the IGBT?". IEEE Photovoltaic Specialists Conference (PVSC) $37^{\text {th }}$ 1842 - 1847. 2011.

[8] J. D. Flicker, R. Kaplar, M. Marinella, and J. Granata. "PV inverter performance and reliability: What is the role of the bus capacitor?" IEEE Photovoltaic Specialists Conference (PVSC). Volume 2: 1-3. 2012

[9] I N. S. Kumara, M. Ashari, A. S. Sampeallo, A. A. G. A Pawitra, (In Press). "Simulated Energy Production and Performance Ratio of 5 MW Grid-connected Photovoltaic under Tropical Savannah Climate in Kupang Timor Island of Indonesia". International Journal of Engineering and Technology Innovation.

[10] BPS Bangli. Statistik Daerah Kabupaten Bangli 2015. Bangli: BPS Bangli. 2015.

[11] I N. S. Kumara, W.G. Ariastina, I W. Sukerayasa and I. A. D. Giriantari. "1 MWp grid connected PV systems in the Village of Kayubihi Bali; review on location's characteristics and its technical specifications". International Conference on Information Technology and Electrical Engineering (ICITEE) 2013. 10.1109/ICITEED.2013.6676258. 2013.

[12] (2011) Florida Solar Energy Center website. [Online] Available: http://www.fsec.ucf.edu/en/consumer/solar electricity/basics/types of pv.htm.

[13] A. Miller and B. Lumby. Utility Scale Solar Power Plants A Guide For Developers and Investors. India: International Finance Corporation (IFC). 2012.

[14] ABB. Technical Application Papers No. 10 Photovoltaic Plants. Bergamo, Italy: ABB SACE. 2010.

[15] I K. A. Setiawan, I N. S. Kumara, and I W. Sukerayasa. "Analisa unjuk kerja pembangkit listrik tenaga surya (PLTS) $1 \mathrm{MWp}$ terinterkoneksi jaringan di Kayubihi Bangli”. Majalah Ilmiah Teknologi Elektro. Vol 13 No. 1.2014

[16] Recommended Practice for Utility Interface of Photovoltaic (PV) Systems, IEEE Std. 929-2000. 
LAMPIRAN

TABEL I

TOTAL PRODUKSI ENERGI MASING-MASING INVERTER

\begin{tabular}{|c|c|c|c|c|c|c|c|c|c|c|c|c|c|}
\hline \multirow{2}{*}{ Inverter } & \multicolumn{12}{|c|}{ SUM Energi (kWh) } & \multirow{2}{*}{$\begin{array}{c}\text { Total Energ } \\
(\mathbf{k W h})\end{array}$} \\
\hline & Jan & Feb & Mar & Apr & Mei & Jun & Jul & Agu & Sep & Okt & Nov & Des & \\
\hline INV 1-D5 & 1757 & 1080 & 1440 & 848 & 1743 & 1613 & 1261 & 663 & & & & & 10405 \\
\hline$I N V 2-D 6$ & 1934 & 1226 & 1662 & 943 & 1896 & 1848 & 1607 & 833 & & & & & 11949 \\
\hline INV 3-D7 & 1900 & 1203 & 1670 & 992 & 1887 & 1865 & 1618 & 881 & & & & & 12016 \\
\hline$I N V 4-D 8$ & 1796 & 1140 & 1612 & 947 & 1778 & 1731 & 1501 & 813 & & & & & 11318 \\
\hline INV 5-D9 & 1771 & 1123 & 1614 & 948 & 1726 & 1695 & 1468 & 781 & & & & & 11126 \\
\hline INV 6-D10 & 1761 & 1130 & 1596 & 921 & 1683 & 1654 & 1454 & 758 & & & & & 10957 \\
\hline INV 7-D4 & 1822 & 1181 & 1685 & 970 & 1785 & 1715 & 1477 & 814 & & & & & 11449 \\
\hline INV 8-D3 & 1418 & 1008 & 1257 & 922 & 1477 & 1342 & 1071 & 403 & & & & & 8898 \\
\hline INV 9-D2 & 1758 & 1147 & 1651 & 947 & 1754 & 1702 & 1472 & 811 & & & & & 11242 \\
\hline INV 10-D1 & 1970 & 1277 & 1794 & 1039 & 1926 & 1914 & 1691 & 908 & & & & & 12519 \\
\hline INV 11-C5 & 1886 & 993 & 854 & 493 & 918 & 906 & 792 & 545 & 876 & 821 & 77 & 498 & 9659 \\
\hline INV 12-C4 & 1926 & 1245 & 1774 & 1018 & 1890 & 1867 & 1634 & 1122 & 1814 & 1715 & 160 & 1004 & 17169 \\
\hline$I N V 13-C 2$ & 1933 & 1250 & 1767 & 1025 & 1894 & 1877 & 1654 & 1127 & 1796 & 1711 & 162 & 1012 & 17208 \\
\hline INV 14-C1 & 1963 & 1264 & 1787 & 1032 & 1914 & 1897 & 1675 & 1143 & 1839 & 1683 & 166 & 1059 & 17422 \\
\hline INV 15-A10 & 1917 & 1234 & 1763 & 1019 & 1889 & 1882 & 1655 & 1123 & 1791 & 1642 & 161 & 1018 & 17094 \\
\hline INV 16-A9 & 1599 & 1034 & 1465 & 848 & 1582 & 1584 & 1393 & 937 & 1487 & 1369 & 135 & 854 & 14287 \\
\hline INV 17-A8 & 1540 & 998 & 1426 & 826 & 1552 & 1540 & 1356 & 917 & 1474 & 1412 & 132 & 833 & 14006 \\
\hline INV 18-A7 & 1538 & 998 & 1427 & 820 & 1536 & 1521 & 1334 & 904 & 1460 & 1395 & 132 & 836 & 13901 \\
\hline INV 19-A6 & 1639 & 1065 & 1503 & 874 & 1616 & 1617 & 1432 & 971 & 1549 & 1477 & 139 & 890 & 14772 \\
\hline INV 20-A5 & 1592 & 1034 & 1480 & 855 & 1574 & 1546 & 1350 & 930 & 1522 & 1447 & 135 & 860 & 14325 \\
\hline INV 21-A4 & 1897 & 1224 & 1758 & 1013 & 1898 & 1870 & 1630 & 1111 & 1782 & 1631 & 160 & 1015 & 16989 \\
\hline INV 22-A3 & 1922 & 1241 & 1772 & 1024 & 1886 & 1862 & 1638 & 1122 & 1801 & 1644 & 162 & 1039 & 17113 \\
\hline INV 23-A2 & 1885 & 1215 & 1738 & 1000 & 1865 & 1841 & 1605 & 1088 & 1719 & 1562 & 156 & 992 & 16666 \\
\hline INV 24-AI & 1865 & 1207 & 1730 & 999 & 1843 & 1828 & 1599 & 1081 & 1718 & 1554 & 153 & 984 & 16561 \\
\hline INV 25-C7 & 1962 & 1256 & 1754 & 1009 & 1866 & 1758 & 1445 & 961 & 1701 & 1590 & 144 & 821 & 16267 \\
\hline INV 26-C6 & 1994 & 1283 & 1813 & 1048 & 1956 & 1892 & 1568 & 1020 & 1865 & 1727 & 168 & 1014 & 17348 \\
\hline INV 27-C3 & 1867 & 1210 & 1741 & 1003 & 1876 & 1831 & 1598 & 1095 & 1775 & 1662 & 158 & 968 & 16784 \\
\hline INV 28-B10 & 1643 & 1065 & 1505 & 867 & 1614 & 1605 & 1405 & 957 & 1561 & 1429 & 140 & 868 & 14659 \\
\hline INV 29-B9 & 1675 & 1083 & 1517 & 875 & 1641 & 1643 & 1440 & 965 & 1570 & 1483 & 142 & 913 & 14947 \\
\hline INV 30-B8 & 1655 & 1071 & 1515 & 876 & 1625 & 1633 & 1440 & 956 & 1586 & 1516 & 140 & 851 & 14864 \\
\hline INV 31-B7 & 1673 & 1084 & 1526 & 885 & 1654 & 1646 & 1447 & 989 & 1602 & 1462 & 141 & 887 & 14996 \\
\hline INV 32-B6 & 1500 & 979 & 1408 & 812 & 1519 & 1487 & 1282 & 884 & 1477 & 1347 & 126 & 779 & 13600 \\
\hline INV 33-B5 & 1606 & 1042 & 1490 & 857 & 1557 & 1518 & 1346 & 933 & 1570 & 1433 & 136 & 861 & 14349 \\
\hline INV 34-B4 & 1645 & 1068 & 1510 & 875 & 1632 & 1587 & 1401 & 959 & 1566 & 1420 & 140 & 887 & 14690 \\
\hline INV 35-B3 & 1562 & 1018 & 1461 & 843 & 1570 & 1547 & 1360 & 933 & 1517 & 1374 & 132 & 836 & 14153 \\
\hline INV 36-B2 & 1608 & 1046 & 1486 & 856 & 1588 & 1571 & 1367 & 920 & 1533 & 1394 & 135 & 855 & 14359 \\
\hline INV 37-B1 & 1516 & 991 & 1433 & 820 & 1500 & 1461 & 1258 & 857 & 1450 & 1320 & 126 & 778 & 13510 \\
\hline INV 38-C8 & 1865 & 1222 & 1775 & 1010 & 1755 & 1665 & 1430 & 977 & 1843 & 1672 & 156 & 963 & 16333 \\
\hline INV 39-C9 & 1933 & 1269 & 1807 & 1041 & 1912 & 1815 & 1561 & 1078 & 1882 & 1714 & 165 & 1036 & 17213 \\
\hline INV 40-E1 & 1969 & 1263 & 1753 & 1005 & 1814 & 1743 & 1547 & 1086 & 1850 & 1690 & 162 & 1035 & 16917 \\
\hline INV 41-C10 & 1932 & 1250 & 1792 & 1031 & 1942 & 1910 & 1624 & 1088 & 1880 & 1717 & 163 & 1034 & 17363 \\
\hline INV 42-E4 & 1943 & 1261 & 1793 & 1031 & 1940 & 1902 & 1680 & 1143 & 1895 & 1724 & 166 & 1038 & 17516 \\
\hline INV 43-E2 & 1644 & 1079 & 1504 & 876 & 1613 & 1611 & 1431 & 980 & 1604 & 1452 & 139 & 881 & 14814 \\
\hline INV 44-E5 & 2009 & 1301 & 1834 & 1055 & 1978 & 1904 & 1636 & 1129 & 1943 & 1778 & 172 & 1088 & 17827 \\
\hline INV 45-E6 & 1663 & 1080 & 1528 & 881 & 1619 & 1593 & 1332 & 901 & 1617 & 1483 & 134 & 858 & 14689 \\
\hline INV 46-E3 & 1555 & 1011 & 1350 & 754 & 1397 & 1469 & 1293 & 882 & 1507 & 1373 & 126 & 801 & 13518 \\
\hline INV 47-E7 & 1642 & 1062 & 1498 & 881 & 1630 & 1585 & 1412 & 964 & 1590 & 1423 & 131 & 839 & 14657 \\
\hline INV 48-E8 & 1587 & 1010 & 1336 & 775 & 1466 & 1479 & 1265 & 854 & 1486 & 1380 & 133 & 836 & 13607 \\
\hline INV 49-E9 & 1696 & 1097 & 1502 & 849 & 1494 & 1462 & 1281 & 862 & 1603 & 1480 & 145 & 914 & 14385 \\
\hline INV 50-E10 & 1641 & 1063 & 1480 & 855 & 1578 & 1564 & 1362 & 932 & 1559 & 1417 & 136 & 846 & 14433 \\
\hline
\end{tabular}


TABEL II

RATA-RATA PRODUKSI ENERGI MASING-MASING INVERTER

\begin{tabular}{|c|c|c|c|c|c|c|c|c|c|c|c|c|c|}
\hline \multirow{2}{*}{ Inverter } & \multicolumn{12}{|c|}{ Rata-rata Produksi Energi Harian (kWh) } & \multirow{2}{*}{$\begin{array}{l}\text { Rata-rata } \\
\text { Setahun } \\
\text { (kWh)* }\end{array}$} \\
\hline & Jan & Feb & Mar & Apr & Mei & Jun & Jul & Agu & Sep & Okt & Nov & Des & \\
\hline INV 1-D5 & 56,68 & 54,00 & 72,00 & 56,53 & 75,78 & 53,77 & 40,68 & 55,25 & & & & & 57,17 \\
\hline INV 2-D6 & 62,39 & 61,30 & 83,10 & 62,87 & 82,43 & 61,60 & 51,84 & 69,42 & & & & & 65,65 \\
\hline INV 3-D7 & 61,29 & 60,15 & 83,50 & 66,13 & 82,04 & 62,17 & 52,19 & 73,42 & & & & & 66,02 \\
\hline$I N V$ 4-D8 & 57,94 & 57,00 & 80,60 & 63,13 & 77,30 & 57,70 & 48,42 & 67,75 & & & & & 62,19 \\
\hline INV 5-D9 & 57,13 & 56,15 & 80,70 & 63,20 & 75,04 & 56,50 & 47,35 & 65,08 & & & & & 61,13 \\
\hline$I N V$ 6-D10 & 56,81 & 56,50 & 79,80 & 61,40 & 73,17 & 55,13 & 46,90 & 63,17 & & & & & 60,20 \\
\hline INV 7-D4 & 58,77 & 59,05 & 84,25 & 64,67 & 77,61 & 57,17 & 47,65 & 67,83 & & & & & 62,91 \\
\hline$I N V$ 8-D3 & 45,74 & 50,40 & 62,85 & 61,47 & 64,22 & 44,73 & 34,55 & 33,58 & & & & & 48,89 \\
\hline INV 9-D2 & 56,71 & 57,35 & 82,55 & 63,13 & 76,26 & 56,73 & 47,48 & 67,58 & & & & & 1,77 \\
\hline$I N V$ 10-D1 & 63,55 & 63,85 & 89,70 & 69,27 & 83,74 & 63,80 & 54,55 & 75,67 & & & & & 68,79 \\
\hline INV 11-C5 & 60,84 & 49,65 & 42,70 & 32,87 & 39,91 & 30,20 & 25,55 & 34,06 & 48,67 & 45,61 & 25,67 & 23,71 & 39,26 \\
\hline INV 12-C4 & 62,13 & 62,25 & 88,70 & 67,87 & 82,17 & 62,23 & 52,71 & 70,13 & 100,78 & 95,28 & 53,33 & 47,81 & 9,79 \\
\hline$I N V 13-C 2$ & 62,35 & 62,50 & 88,35 & 68,33 & 82,35 & 62,57 & 53,35 & 70,44 & 99,78 & 95,06 & 54,00 & 48,19 & 69,95 \\
\hline$I N V$ 14-C1 & 63,32 & 63,20 & 89,35 & 68,80 & 83,22 & 63,23 & 54,03 & 71,44 & 102,17 & 93,50 & 55,33 & 50,43 & 0,82 \\
\hline INV 15-A10 & 61,84 & 61,70 & 88,15 & 67,93 & 82,13 & 62,73 & 53,39 & 70,19 & 99,50 & 91,22 & 53,67 & 48,48 & 69,49 \\
\hline INV 16-A9 & 51,58 & 51,70 & 73,25 & 56,53 & 68,78 & 52,80 & 44,94 & 58,56 & 82,61 & 76,06 & 45,00 & 40,67 & 58,08 \\
\hline INV 17-A8 & 49,68 & 49,90 & 71,30 & 55,07 & 67,48 & 51,33 & 43,74 & 57,31 & 81,89 & 78,44 & 44,00 & 39,67 & 6,93 \\
\hline INV 18-A7 & 49,61 & 49,90 & 71,35 & 54,67 & 66,78 & 50,70 & 43,03 & 56,50 & 81,11 & 77,50 & 44,00 & 39,81 & 6,51 \\
\hline INV 19-A6 & 52,87 & 53,25 & 75,15 & 58,27 & 70,26 & 53,90 & 46,19 & 60,69 & 86,06 & 82,06 & 46,33 & 42, & 0,05 \\
\hline INV 20-A5 & 51,35 & 51,70 & 74,00 & 57,00 & 68,43 & 51,53 & 43,55 & 58,13 & 84,56 & 80,39 & 45,00 & 40,95 & 8,23 \\
\hline$I N V$ 21-A4 & 61,19 & 61,20 & 87,90 & 67,53 & 82,52 & 62,33 & 52,58 & 69,44 & 99,00 & 90,61 & 53,33 & 48,33 & 69,06 \\
\hline$I N V$ 22-A3 & 62,00 & 62,05 & 88,60 & 68,27 & 82,00 & 62,07 & 52,84 & 70,13 & 100,06 & 91,33 & 54,00 & 49,48 & 69,57 \\
\hline INV 23-A2 & 60,81 & 60,75 & 86,90 & 66,67 & 81,09 & 61,37 & 51,77 & 68,00 & 95,50 & 86,78 & 52,00 & 47,24 & 7,75 \\
\hline INV 24-AI & 60,16 & 60,35 & 86,50 & 66,60 & 80,13 & 60,93 & 51,58 & 67,56 & 95,44 & 86,33 & 51,00 & 46,86 & 67,32 \\
\hline INV 25-C7 & 63,29 & 62,80 & 87,70 & 67,27 & 81,13 & 58,60 & 46,61 & 60,06 & 94,50 & 88,33 & 48,00 & 39,10 & 66,13 \\
\hline INV 26-C6 & 64,32 & 64,15 & 90,65 & 69,87 & 85,04 & 63,07 & 50,58 & 63,75 & 103,61 & 95,94 & 56,00 & 48,29 & 70,52 \\
\hline INV 27-C3 & 60,23 & 60,50 & 87,05 & 66,87 & 81,57 & 61,03 & 51,55 & 68,44 & 98,61 & 92,33 & 52,67 & 46,10 & 68,23 \\
\hline INV 28-B10 & 53,00 & 53,25 & 75,25 & 57,80 & 70,17 & 53,50 & 45,32 & 59,81 & 86,72 & 79,39 & 46,67 & 41,33 & 9,59 \\
\hline INV 29-B9 & 54,03 & 54,15 & 75,85 & 58,33 & 71,35 & 54,77 & 46,45 & 60,31 & 87,22 & 82,39 & 47,33 & 43,48 & 60,76 \\
\hline INV 30-B8 & 53,39 & 53,55 & 75,75 & 58,40 & 70,65 & 54,43 & 46,45 & 59,75 & 88,11 & 84,22 & 46,67 & 40,52 & 60,42 \\
\hline INV 31-B7 & 53,97 & 54,20 & 76,30 & 59,00 & 71,91 & 54,87 & 46,68 & 61,81 & 89,00 & 81,22 & 47,00 & 42,24 & 60,96 \\
\hline INV 32-B6 & 48,39 & 48,95 & 70,40 & 54,13 & 66,04 & 49,57 & 41,35 & 55,25 & 82,06 & 74,83 & 42,00 & 37,10 & 55,28 \\
\hline INV 33-B5 & 51,81 & 52,10 & 74,50 & 57,13 & 67,70 & 50,60 & 43,42 & 58,31 & 87,22 & 79,61 & 45,33 & 41,00 & 58,33 \\
\hline INV 34-B4 & 53,06 & 53,40 & 75,50 & 58,33 & 70,96 & 52,90 & 45,19 & 59,94 & 87,00 & 78,89 & 46,67 & 42,24 & 59,72 \\
\hline INV 35-B3 & 50,39 & 50,90 & 73,05 & 56,20 & 68,26 & 51,57 & 43,87 & 58,31 & 84,28 & 76,33 & 44,00 & 39,81 & 57,53 \\
\hline INV 36-B2 & 51,87 & 52,30 & 74,30 & 57,07 & 69,04 & 52,37 & 44,10 & 57,50 & 85,17 & 77,44 & 45,00 & 40,71 & 58,37 \\
\hline INV 37-B1 & 48,90 & 49,55 & 71,65 & 54,67 & 65,22 & 48,70 & 40,58 & 53,56 & 80,56 & 73,33 & 42,00 & 37,05 & 54,92 \\
\hline$I N V 38-C 8$ & 60,16 & 61,10 & 88,75 & 67,33 & 76,30 & 55,50 & 46,13 & 61,06 & 102,39 & 92,89 & 52,00 & 45,86 & 66,39 \\
\hline INV 39-C9 & 62,35 & 63,45 & 90,35 & 69,40 & 83,13 & 60,50 & 50,35 & 67,38 & 104,56 & 95,22 & 55,00 & 49,33 & 69,97 \\
\hline INV 40-E1 & 63,52 & 63,15 & 87,65 & 67,00 & 78,87 & 58,10 & 49,90 & 67,88 & 102,78 & 93,89 & 54,00 & 49,29 & 68,77 \\
\hline INV 41-C10 & 62,32 & 62,50 & 89,60 & 68,73 & 84,43 & 63,67 & 52,39 & 68,00 & 104,44 & 95,39 & 54,33 & 49,24 & 70,58 \\
\hline INV 42-E4 & 62,68 & 63,05 & 89,65 & 68,73 & 84,35 & 63,40 & 54,19 & 71,44 & 105,28 & 95,78 & 55,33 & 49,43 & 71,20 \\
\hline INV 43-E2 & 53,03 & 53,95 & 75,20 & 58,40 & 70,13 & 53,70 & 46,16 & 61,25 & 89,11 & 80,67 & 46,33 & 41,95 & 60,22 \\
\hline INV 44-E5 & 64,81 & 65,05 & 91,70 & 70,33 & 86,00 & 63,47 & 52,77 & 70,56 & 107,94 & 98,78 & 57,33 & 51,81 & 72,47 \\
\hline INV 45-E6 & 53,65 & 54,00 & 76,40 & 58,73 & 70,39 & 53,10 & 42,97 & 56,31 & 89,83 & 82,39 & 44,67 & 40,86 & 59,71 \\
\hline INV 46-E3 & 50,16 & 50,55 & 67,50 & 50,27 & 60,74 & 48,97 & 41,71 & 55,13 & 83,72 & 76,28 & 42,00 & 38,14 & 54,95 \\
\hline INV 47-E7 & 52,97 & 53,10 & 74,90 & 58,73 & 70,87 & 52,83 & 45,55 & 60,25 & 88,33 & 79,06 & 43,67 & 39,95 & 59,58 \\
\hline INV 48-E8 & 51,19 & 50,50 & 66,80 & 51,67 & 63,74 & 49,30 & 40,81 & 53,38 & 82,56 & 76,67 & 44,33 & 39,81 & 55,31 \\
\hline INV 49-E9 & 54,71 & 54,85 & 75,10 & 56,60 & 64,96 & 48,73 & 41,32 & 53,88 & 89,06 & 82,22 & 48,33 & 43,52 & 58,48 \\
\hline INV 50-E10 & 52,94 & 53,15 & 74,00 & 57,00 & 68,61 & 52,13 & 43,94 & 58,25 & 86,61 & 78,72 & 45,33 & 40,29 & 58,67 \\
\hline
\end{tabular}

* Rata-rata produksi energi harian selama setahun, diperoleh dengan merata-ratakan produksi energi inverter bersangkutan setiap hari selama satu tahun 